\title{
PERSPECTIVES OF TALENT MANAGEMENT: EVIDENCE FROM CZECH AND SLOVAK BUSINESS ORGANISATIONS
}

\section{Dana Egerová, Drahoslav Lančarič, Ludvík Eger, Radovan Savov}

\section{Introduction}

Talent management has recently emerged as one of the key issues facing organizations and will undoubtedly continue being an important challenge for management [11], [21], [29]. The consensus among the academic community is that the management of talent represents an important source of competitive advantage for organizations worldwide and that the prosperity of an organization depends on its ability to manage its talents effectively [4], [24]. Thus, organisations striving to survive in the current highly competitive and uncertain business environment must consider talent management as a key organisational and management issue.

Despite the growing popularity of talent management in the literature, the current conceptualisation of talent management remains narrow and limited [9]. The lack of empirical research on applications of talent management in different contexts [8], [32] is a serious limitation. Although there is a wide range of external and internal factors that influence the use of talent management practices, the awareness of talent management in different types of organisations and national contexts is weak [21]. Thus, some authors [34], [39] call for a broader approach to talent management and a consideration of the importance of context.

The current conceptualisation of talent management strongly focuses on multinational companies and large domestic organizations [21], [25]. However, human resource management and talent management are becoming increasingly important in small and medium-sized enterprises (SMEs), and talent management in SMEs is different from that in large organisations [22].

This study aims to contribute to the research on talent management through an empirical investigation of talent management practices in business organisations in the
Czech Republic and Slovakia. Specifically, the study explores the extent to which differently sized organisations in these countries engage in talent management. We thus provide needed empirical evidence on talent management that may differ from the current models and thus advance the conceptual and empirical grounding of this area.

This paper begins with a brief overview of the current views on talent and talent management. Then, the methodology and findings of the empirical study are presented and discussed. The paper concludes with a summary and a the study's limitations and suggestions for further research.

\section{Talent and Talent Management: Existing Perspectives}

This section reviews briefly the current understanding of the concepts of 'talent' and 'talent management'. To determine the concept of 'talent management', it is important to discuss the meaning of 'talent'. To make talent management effective, organisations need to know whom to regard as a talent [42], [24]. There is no unanimous definition of 'talent', and many interpretations and approaches to talent have been taken in the business context (e.g. [3], [8], [9]). According to Thunnissen, Boselie and Fruytier [35] without a consensus on the meaning of 'talent', talent management research cannot be advanced. On the other hand, talent management in organisations is clearly largely determined by the definition of 'talent' itself, which is strongly influenced by the organisational context [6], [20]. This inspires two questions: Can the definition of 'talent' be truly universal, and to what extent does the lack of a universal definition of 'talent' really matter [34]. We argue that a balanced approach to the definition of 'talent' is needed in order to consider different theoretical approaches to it as well as specific organisational contexts for it. 
Based on a review of the talent management literature the authors [9] have grouped theoretical approaches to talent into 'object' approaches (where talent refers to human characteristics, such as talent as a natural ability, mastery; commitment; or a fit) and 'subject' approaches (where talent refers to people). Within the subject approach, they have identified the inclusive approach (where talent is understood as concerning all employees) and the exclusive approach (where talent focuses on a select group of high-performing and/or high-potential employees). Different combinations of these approaches generate different talent management models [36], [9]. According to authors [33] a 'hybrid' approach is most commonly used in organisations. In our survey, talent generally refers to employees (using the subject approach).

Although talent management has received much attention from practitioners and academics in recent years, the clarity of its definition, scope, and overall goals is lacking [3], [36]. Lewis and Heckman [18] add that finding a precise meaning of 'talent management' in the talent management literature is difficult. Four main views concerning talent management co-exist in the organisational context [2]: talent management as a collection of typical human resource department practices, functions, or activities; talent management as a set of processes designed to ensure an adequate flow of employees into jobs; and talent management focusing on talent generically [18]. The above three perspectives tend to focus on one aspect of talent management [7], [36]. To go beyond this single approach, Collings and Mellahi [3] added a fourth stream emphasizing the identification of key positions able to differentially impact firms' competitive advantages. This view represents a strategic perspective on talent management. According to the authors [10] talent management cannot be isolated from business strategies. Silzer and Dowell [30] stress that talent management ought to be strategically driven and integrated with other organisational programs and systems.

For purpose of our study we adopt the definition proposed by Silzer and Dowell [30, p.18] "Talent management is an integrated set of processes, programs, and cultural norms in an organisation designed and implemented to attract, develop, deploy, and retain talent to achieve strategic objectives and meet future business needs."

It is also important to note that the implementation of talent management varies among organisations and is heavily influenced by internaland external factors specifictoeach society and organisation (e.g. [2], [28], [33]). The key factors affecting talent management are changes in economics, the world of work, demography, culture, and politics [12], [29]. Similarly, Bersin [1] identifies the following factors affecting corporate talent management: rapid business changes, a shift towards emerging markets, the borderless workplace, new job types and career models, and intense competition for talent. The internal factors are related to the internal environment and may encompass organisational strategy, organisational structure, organisational culture, management involvement, employee values, or workforce policy [17], [30]. Thus, organisations must consider and understand both the external and internal factors in order to be able to manage talent effectively and efficiently. With Thunnissen, Boselie and Fruytier [36] we also argue that talent management needs to be studied in isolation as well as across different contexts.

\section{Methodology}

The purpose of this study was to investigate and compare talent management practises among differently sized enterprises in the Czech Republic and Slovakia. Since talent management is still perceived as a new phenomenon in the Czech Republic and Slovakia, the descriptive (initial mapping of the field) and exploratory (clarifying differences in talent management implementations in differently sized enterprises) research approaches have been chosen.

The background investigation was important in order to identify the characteristics and factors influencing the successful implementation of talent management in differently sized enterprises.

\subsection{Research Questions and Hypotheses}

This study provides an answer to the following central research question: What is talent management today in Czech and Slovak enterprises?

In addition to the central research question, the following specific research questions, based on the desk research results, were formulated: 
- What approaches to talent management do enterprises in the Czech Republic and Slovakia adopt?

- Which talent management practices are used by enterprises in the Czech Republic and Slovakia?

Based on the literature review and given the specific research questions, the following data-collection questions and hypotheses were formulated:

(1) What approach with respect to their size do the enterprises adopt to define 'talent'?

\section{Hypothesis No. 1:}

Hypothesis 1a: Small and medium-sized enterprises adopt the inclusive approach to talent.

Hypothesis 1b: Large enterprises adopt the exclusive approach to talent.

(2) Is the size of an enterprise a determinant of its strategic approach to talent management?

Hypothesis No. 2: The strategic approach to talent management is determined by the size of an enterprise.

(3) Are there any differences in the implementation of talent management practices between large enterprises and SMEs in the Czech Republic and Slovakia?

Hypothesis No. 3:

Hypothesis $\mathrm{H}_{0}$ : There are no differences in the implementation of talent management practices between large and small and medium-sized enterprises in the Czech Republic and Slovakia. Hypothesis $\mathrm{H}_{A}$ : There are differences in the implementation of talent management practices between large and small and medium-sized enterprises in the Czech Republic and Slovakia.

\subsection{Research Method and Tools}

Selective survey as a method to gather primary data was used. According to Munk et al. [23] the selective survey means that the chosen data are only part of basic file and therefore the accuracy of results is limited. The selective file was determined randomly. A scale questionnaire (both print and internet mediated versions) of the author's own construction was used as a tool of data collection. It contained 41 items divided into the following five areas: talent management and the overall business strategy (nine items), identification and recruitment of talent (11 items), talent assessment (seven items), talent development (seven items), and talent retention (seven items).

The individual items were accompanied by a 5-point Likert scale with options ranging from 1 (definitely disagree) to 5 (definitely agree) for all items. In order to reduce any noise in the data "not applicable options" was also included in the response scale. This added point allowed respondents to indicate that they do not have an opinion on a particular issue concerning TM.

\subsection{Validity and Reliability of the Questionnaire}

The questionnaire was first tested by three experts and then by a small group of participants. The reliability of the questionnaire was statistically assessed by using Cronbach's coefficient alpha for the areas of the questionnaire. The areas, number of items, and the calculated result are as follows: Talent management and the overall business strategy (nine items), Cronbach $\alpha=0.979$; Identification and recruitment of talent (11 items), Cronbach $\alpha=0.790$; Talent assessment (seven items), Cronbach $\alpha=0.827$; Talent development (seven items), Cronbach $\alpha=0.701$; Talent retention (seven items), Cronbach $\alpha=0.775$; Total reliability, Cronbach $\alpha=0.929$.

\subsection{Testing the Research Hypotheses}

Owing to the character of the collected data, non-parametric statistical methods were used. To verify the existence of statistically significant differences between the individual groups of respondents (depending on a particular factor; see the classification units), the Mann-Whitney, Kruskal-Wallis, and Jonckheere-Terpstra tests were used. The Mann-Whitney test is a nonparametric alternative to the t-test. The KruskalWallis test is a non-parametric parallel of a oneway analysis of variance (ANOVA). The aim of the tests is to determine whether the differences of the medians found in the sample of the individual groups are statistically significant (meaning there is a relationship between the variables) or coincidental (meaning there is no relationship). A null statistical hypothesis with parity among all the medians is tested. If the $p$-value is lower than the chosen level of significance (traditionally $5 \%=0.05$ ), the null hypothesis is rejected, meaning that the difference between at least one pair of the medians calculated from the sample is too large to be a result of only random selection 
(i.e. it is statistically significant, as there is a relationship between the variables). If the $\mathrm{p}$-value is equal or higher than the chosen level of significance, the null hypothesis cannot be rejected, meaning that the difference between each pair of the medians calculated from the sample can be a result only of random selection (i.e. it is not statistically significant, as there is no relationship between the variables; [23]). To test the existence of a statistically significant difference, suitable methods of 'post hoc testing' were used (i.e. Tukey`s HSD test). To examine the differences within categorical variables (research question 1), we used a chisquare test of goodness-of-fit.

\subsection{Sample Characteristics}

A quantitative research study encompassing 174 enterprises (68 from the Slovak Republic and 106 from the Czech Republic) was conducted between June and August 2013. Regarding enterprise size, the intervals of the number of employees corresponded to the EU's enterprise size typology (SME definition adopted by the Commission, 2003). Each business subject was represented by one respondent, an owner of an SME or a manager or HR specialists of an SME or large enterprise - in other words, those responsible for HRM and who are most familiar with the business situation of their enterprises.

Tab. 1: Size of the enterprise

\begin{tabular}{l|r|r|r|r}
\multirow{2}{*}{} & \multicolumn{2}{|c|}{ Slovak Republic } & \multicolumn{2}{c}{ Czech Republic } \\
\cline { 2 - 5 } & \multicolumn{1}{|c|}{ Count } & \multicolumn{1}{c}{ \% } & \multicolumn{1}{c}{ Count } & \multicolumn{1}{c}{$\%$} \\
\hline small (10-50 employees) & 32 & 47 & 25 & 24 \\
\hline medium (51-250 employees) & 19 & 28 & 28 & 26 \\
\hline large (over 251 employees) & 17 & 25 & 53 & 50 \\
\hline total & 68 & 100 & 106 & 100 \\
\hline
\end{tabular}

Source: own

\section{Findings and Discussion Question No. 1:}

What approach with respect to their size do the enterprises adopt to define 'talent'?

\section{Hypothesis No. 1:}

Hypothesis 1a: Small and medium-sized enterprises adopt the inclusive approach to talent.

Hypothesis 1b: Large enterprises adopt the exclusive approach to talent.

To answer research question 1 and verify hypothesis 1 , we tested the attitudes of respondents to questionnaire items 8 and 12 ('We search for talent in every single person that has just been employed' and 'We are currently identifying talents among all the workers employed in our company' respectively). Both items clearly indicate that there are no differences in approaches to employees with regard to the search for talent and its identification. Therefore, we assume that respondents taking the inclusive approach will tend to agree with statements in items 8 and 12. To determine what approach is adopted in small and medium-sized enterprises, we used the size of the enterprise as a grouping variable (there were three categories: small, medium, and large enterprises). The results are presented in Tab. 2 to 5 . Not all of the respondents expressed their attitudes towards the statements in the individual items, hence the differences in the total number of respondents in items 8 and 12.

As the results show, the small and mediumsized enterprises adopt the exclusive approach, while the large enterprises adopt the inclusive approach. This result was confirmed by the chi-square test of goodness-of-fit (see Tab. 3 and 5). Thus, hypotheses $1 \mathrm{a}$ and $1 \mathrm{~b}$ were not confirmed.

Therefore, we conclude that small and medium-sized enterprises in the Czech Republic and Slovakia adopt the exclusive approach to define 'talent' and that large enterprises adopt the inclusive approach. 


\section{Ekonomika a management}

\section{Tab. 2: Respondents`attitudes - item 8}

\begin{tabular}{|c|c|c|c|c|c|c|c|}
\hline & \multicolumn{5}{|c|}{ I_8 } & \multirow{2}{*}{ Total } \\
\hline & & 1 & 2 & 3 & 4 & 5 & \\
\hline \multirow[t]{3}{*}{ Size } & small (10-50 employees) & 17 & 7 & 12 & 12 & 5 & 53 \\
\hline & $\begin{array}{l}\text { medium (51-250 } \\
\text { employees) }\end{array}$ & 8 & 10 & 13 & 10 & 3 & 44 \\
\hline & $\begin{array}{l}\text { large (over } 251 \\
\text { employees) }\end{array}$ & 4 & 10 & 12 & 26 & 11 & 63 \\
\hline \multicolumn{2}{|l|}{ Total } & 29 & 27 & 37 & 48 & 19 & 160 \\
\hline
\end{tabular}

\section{Tab. 3: $\quad$ Results of Chi-Square test - item 8}

\begin{tabular}{l|c|c|c} 
& Value & df & P \\
\hline Pearson Chi-Square & 20.37 & 8 & $0.01^{*}$ \\
\hline Likelihood Ratio & 20.70 & 8 & $0.01^{*}$ \\
\hline Linear-by-linear Association & 12.36 & 1 & $0.00^{*}$ \\
\hline N of Valid Cases & 160 & & \\
\hline
\end{tabular}

* indicates statistical significance at significance level 0.01

\section{Tab. 4: Respondents`attitudes - item 12}

\begin{tabular}{|c|c|c|c|c|c|c|c|}
\hline & \multicolumn{5}{|c|}{ I_12 } & \multirow{3}{*}{$\begin{array}{r}\text { Total } \\
52\end{array}$} \\
\hline & & 1 & 2 & 3 & 4 & 5 & \\
\hline \multirow[t]{3}{*}{ Size } & small (10-50 employees) & 11 & 13 & 12 & 14 & 2 & \\
\hline & $\begin{array}{l}\text { medium (51-250 } \\
\text { employees) }\end{array}$ & 10 & 8 & 15 & 8 & 4 & 45 \\
\hline & $\begin{array}{l}\text { large (over } 251 \\
\text { employees) }\end{array}$ & 9 & 8 & 5 & 26 & 12 & 60 \\
\hline \multicolumn{2}{|l|}{ Total } & 30 & 29 & 32 & 48 & 18 & 157 \\
\hline
\end{tabular}

\section{Tab. 5: Results of Chi-Square test - item 12}

\begin{tabular}{l|c|c|c} 
& Value & df & P \\
\hline Pearson Chi-Square & 23.64 & 8 & 0.00 \\
\hline Likelihood Ratio & 24.58 & 8 & 0.00 \\
\hline Linear-by-linear Association & 8.85 & 1 & 0.00 \\
\hline N of Valid Cases & 157 & & \\
\hline
\end{tabular}

* indicates statistical significance at significance level 0.01 
This suggests that SMEs base talent on a segmentation of the workforce, whereas large companies take a more humanistic approach, in which all employees have the opportunity to be a talent [14]. These findings are not in line with the results of earlier surveys (e.g. [8], [29], [32]). On the other hand, the findings support the notion that talent is a context-driven concept determined by numerous internal and external factors [17]. For Czech and Slovak organisations, factors such as type of business, key organisational priorities, organisational specifics, company culture, owner/manager knowledge, experiences, values, and attitudes to staff may play an important role.

\section{Question No. 2:}

Is the size of an enterprise a determinant of its strategic approach to talent management?

\section{Hypothesis No. 2:}

The strategic approach to talent management is determined by the size of an enterprise.

There were seven items in the questionnaire dealing with the strategic approach to talent management:

Item 5: We have a clearly defined talent management strategy.
Item 6: Talent management strategy is connected with strategic goals of our organization.

Item 9: A formulated talent management strategy is easy to realize in our company.

Item 18: We know what talents we are going to need in the future.

Item 19: We know how many talented people we are going to need in the future.

Item 31: We develop talents thanks to the plans we implemented.

Item 35: We successfully retain talented people.

We assumed that the respondents working in an enterprise taking a strategic approach to talent management would agree with the statements in the questionnaire items and that the average scores of these items would be higher than 3 (indicating a neutral attitude). Therefore, first, we simply calculated the average scores of each individual questionnaire item dealing with the strategic approach to talent management. The attained scores are seen in Tab. 6.

\section{Tab. 6: Items dealing with the strategic approach to talent management - average scores}

\begin{tabular}{l|c|c|c|c|c|c|c} 
& I_5 & I_6 & I_9 & I_18 & I_19 & I_31 & I_35 \\
\hline $\mathrm{N}$ & 161 & 158 & 135 & 166 & 153 & 158 & 158 \\
\hline Mean & 2.63 & 2.78 & 3.22 & 3.11 & 2.39 & 2.64 & 2.94 \\
\hline
\end{tabular}

Source: own

Out of seven questionnaire items dealing with the strategic approach, only two reached an average score higher than 3 . Most of the average scores were below 3 , indicating that the respondents tended to disagree with the statements in the questionnaire items. These results suggest that the strategic approach to talent management is not clearly developed or, at least, is not clearly developed within some groups of enterprises. To examine the reason for this result in detail, we evaluated the influence of the size of the enterprise on the attitudes of respondents to the strategic approach to talent management in their enterprises.
The size of the company should be considered a strong determinant of the respondents' attitudes. There were statistically significant differences in four questionnaire items out of the seven. The differences were confirmed by the Jonckhere-Terpstra test. To evaluate the mean rank differences between individual size groups of enterprises, we applied Tukey`s HSD test (see Tab. 7).

There were statistically significant differences in the attitudes of respondents working in large and small enterprises in items 5 and 31 . In item 5 , the average score of the large enterprises was 2.94 while the average score of small firms was 2.25 . In item 31 , the 


\begin{tabular}{|c|c|c|c|c|c|c|c|}
\hline Tab. 7: & $\begin{array}{l}\text { dealing } \\
\text { ults of } T\end{array}$ & $\begin{array}{l}h \text { the str } \\
\text { ys HSD }\end{array}$ & gic appro & ich to tale & anage & & \\
\hline \multirow{2}{*}{$\begin{array}{l}\text { Dependent } \\
\text { Variable }\end{array}$} & \multirow{2}{*}{ (I) SIZE } & \multirow{2}{*}{ (J) SIZE } & \multirow{2}{*}{$\begin{array}{c}\text { Mean } \\
\text { Difference } \\
(\mathrm{I}-\mathrm{J})\end{array}$} & \multirow{2}{*}{ Std. Error } & \multirow{2}{*}{$\mathbf{P}$} & \multicolumn{2}{|c|}{$\begin{array}{l}\text { 95\% Confidence } \\
\text { Interval }\end{array}$} \\
\hline & & & & & & $\begin{array}{l}\text { Lower } \\
\text { Bound }\end{array}$ & $\begin{array}{l}\text { Upper } \\
\text { Bound }\end{array}$ \\
\hline \multirow{2}{*}{ I_5 } & \multirow{2}{*}{ Large } & Small & $0.688^{*}$ & 0.229 & 0.009 & 0.147 & 1.230 \\
\hline & & Medium & 0.310 & 0.247 & 0.415 & -0.271 & 0.898 \\
\hline \multirow{2}{*}{ I_6 } & \multirow{2}{*}{ Large } & Small & $0.746^{*}$ & 0.232 & 0.005 & 0.197 & 1.295 \\
\hline & & Medium & $0.592^{*}$ & 0.247 & 0.047 & 0.007 & 1.177 \\
\hline \multirow{2}{*}{ I_31 } & \multirow{2}{*}{ Large } & Small & $0.849^{*}$ & 0.227 & 0.001 & 0.311 & 1.387 \\
\hline & & Medium & 0.490 & 0.236 & 0.097 & -0.068 & 1.052 \\
\hline \multirow{2}{*}{ I_35 } & \multirow{2}{*}{ Large } & Small & $0.771^{*}$ & 0.201 & 0.001 & 0.295 & 1.246 \\
\hline & & Medium & $0.700^{*}$ & 0.213 & 0.004 & 0.195 & 1.205 \\
\hline
\end{tabular}

* indicates statistically significant diference

average score of the large enterprises was 3.04. The average score of the small enterprises was 2.17. The differences between the attitudes of the respondents working in large and small or medium enterprises in items 6 and 35 were even clearer. The average score of the large enterprises in item 6 was 3.18 (2.43 for small and 2.59 for medium); in item 35 , it was 3.37 (2.60 for small and 2.67 for medium). These results show that the respondents working in large enterprises expressed a more positive attitude towards statements in the questionnaire items dealing with the strategic approach to talent management while the respondents working in small or medium enterprise tended to disagree. Thus, hypothesis 2 was confirmed.

First, we argue that the strategic approach to talent management is determined by the size of the enterprise. The results clearly indicate that large organisations tend to developed talent management strategies that align consistently with their overall strategies and goals, unlike SMEs, where the strategic approach to talent management is limited. Various explanations have been offered for why small and mediumsized enterprises do not develop strategic approaches to talent management. In theoretical terms, a talent management strategy needs to be aligned with the company strategy and human resource strategy. Therefore, we argue that the starting point of formulating and performing a talent management strategy is the existence of the organisation and its human resource strategies. Generally, the application of strategic management in the Czech and Slovak business environments is still very weak [31]. Furthermore, most SMEs in both countries prefer short-term planning based on intuition and improvisation. According to Piszczur [27] $44.5 \%$ of Czech and Slovak SMEs have not developed a company strategy. According to another surveys [37] $65 \%$ of Czech SMEs have not developed a human resource strategy, and $46.4 \%$ have not developed a company strategy development plan [15].

Second, the lack of planning skills in SMEs and their limited knowledge of strategic planning create significant barriers to the strategic approach. Owners' and managers' limited knowledge prevents the application of planning techniques and formal planning instruments. According to a survey [13] a lack of knowledge and awareness of talent management is one of the most frequent causes of the weak application of talent management in Czech organisations.

Third, most owners do not perceive strategic planning as being able to improve corporate performance ([31], [41]). From their perspective, strategic planning constrains flexibility and their ability to improvise, which represents the key characteristic of SMEs. Similarly, we argue that the main obstacles to 
strategic planning are lack of know-how, lack of time, conservative thinking, and the fear of change. However, we argue that the strategic approach is an important precondition for talent management success. Furthermore, consistent with prior findings [30], we argue that an explicit alignment needs to be made among company strategy, human resource strategy, and talent strategy. However, the specific characteristics and conditions must be considered.

\section{Question No. 3:}

Are there any differences in the implementation of talent management practices between large enterprises and SMEs in the Czech Republic and Slovakia?

Hypothesis No. 3:

Hypothesis $\mathrm{H}_{0}$ : There are no differences in the implementation of talent management practices between large and small and medium-sized enterprises in the Czech Republic and Slovakia. Hypothesis $H_{A}$ : There are differences in the implementation of talent management practices between large and small and medium-sized enterprises in the Czech Republic and Slovakia.

Hypothesis 3 was verified by a KruskalWallis test (the assumption of normality was violated). As shown in Tab. 8, the highest share of differences was confirmed in the field of talent assessment (seven items out of seven), the talent development field (six items out of seven), and in the field of retaining the talent (six items out of seven). In the field of the identification and recruitment of talent, the share of differences was smaller (six items out of 11).

\section{Tab. 8: Verification of the differences - size of the enterprise}

\begin{tabular}{l|c|c|c|c|c|c|c|c|c|c|c}
$\begin{array}{c}\text { Identification } \\
\text { and } \\
\text { recruitment }\end{array}$ & I_10 & I_11 & I_12 & I_13 & I_14 & I_15 & I_16 & I_17 & I_18 & I_19 & I_20 \\
\hline$p$ value & 0.673 & $\mathbf{0 . 0 0 2}$ & $\mathbf{0 . 0 0 3}$ & $\mathbf{0 . 0 2 2}$ & 0.128 & $\mathbf{0 . 0 1 7}$ & 0.908 & $\mathbf{0 . 0 0 1}$ & $\mathbf{0 . 0 3 9}$ & 0.578 & 0.640 \\
\hline Assessment & I_21 & I_22 & I_23 & I_24 & I_25 & I_26 & I_27 & & & & \\
\hline$p$ value & $\mathbf{0 . 0 0 1}$ & $\mathbf{0 . 0 0 1}$ & $\mathbf{0 . 0 1 0}$ & $\mathbf{0 . 0 3 0}$ & $\mathbf{0 . 0 0 0}$ & $\mathbf{0 . 0 0 3}$ & $\mathbf{0 . 0 0 0}$ & & & & \\
\hline Development & I_28 & I_29 & I_30 & I_31 & I_32 & I_33 & I_34 & & & & \\
\hline p value & $\mathbf{0 . 0 0 2}$ & $\mathbf{0 . 0 0 0}$ & $\mathbf{0 . 0 1 2}$ & $\mathbf{0 . 0 0 1}$ & $\mathbf{0 . 0 0 5}$ & $\mathbf{0 . 0 0 0}$ & 0.426 & & & & \\
\hline Retaining & I_35 & I_36 & I_37 & I_38 & I_39 & I_40 & I_41 & & & & \\
\hline$p$ value & $\mathbf{0 . 0 0 0}$ & 0.871 & $\mathbf{0 . 0 0 0}$ & $\mathbf{0 . 0 0 6}$ & $\mathbf{0 . 0 0 1}$ & $\mathbf{0 . 0 0 4}$ & $\mathbf{0 . 0 0 0}$ & & & & \\
\hline
\end{tabular}

Based on the results of the Kruskal-Wallis test, we reject the null hypothesis and conclude that there are differences in the realization of talent management practices between large and small and medium-sized enterprises in the Czech Republic and Slovakia. The differences have been revealed mainly in talent assessment, talent development, and talent retention - in other words, in all surveyed areas except for identification and recruitment. These findings may be attributable to the differences in the SMEs' characteristics and the specifics of their human resource management. We believe that the level of human resource management represents one of the most significant factors in the degree to which organisations implement and perform talent management practices. We argue that human resource management is still not a priority in many Czech and Slovak companies. It is also important to note that, despite the significant influence of foreign companies' HRM practices on the human resource practices of local firms, the development of modern HRM remains challenging [14].

Some authors (e.g. [16], [40]) argue that HRM in SMEs focuses on operational needs and is more informal. For instance, a survey [37] conducted among Czech SMEs revealed that $84 \%$ of small enterprises and $75 \%$ of medium enterprises provided informal assessments and that only $34 \%$ of the small and $54 \%$ of the medium enterprises provided formal assessments. According to Parry, Stavrou and 
Lazarova [26] HR practices consist mainly of record keeping and staffing rather than motivation, assessment, development, and retention. The weak attention to these areas in Czech and Slovak SMEs may also reflect the traditional resistance within organisations to investing in human capital [16].

Another important factor in the context of talent management practices in SMEs is the economic situation in both countries. Czech and Slovak SMEs were more severely affected by the crisis than were large enterprises. For instance, because of the crisis, many Czech SMEs failed and employment by them remains below pre-crisis levels. Due to this economic situation, SMEs lack the financial resources to invest in human resources, particularly in talent management. On the other hand, the Talent Shortage Survey [19] shows that most organisations in both countries are experiencing no problems filling jobs (with the exception of candidates with technical competencies). According to the survey, employers in the Czech Republic report fewer difficulties with talent shortages and filling positions than do employers in other countries.

However, we can assume that talent management will remain one of the key priorities for organisations and that organisational success will largely depend on firms' ability to manage talent effectively.

\section{Conclusions}

This paper is one of the first to empirically explore the implementation of talent management in business organisations in the Czech Republic and Slovakia. Its purpose was to investigate and compare talent management in differently sized enterprises operating in these countries in order to explore the extent to which those organisations engage in talent management. Overall, the survey clearly indicates that talent management is not of primary concern for most organisations and remains in its infancy. This is in line with the assumption that talent management is a new concept in Central and Eastern Europe [38]. Another major finding is that the size of an enterprise is a relevant determinant of its approach to and implementation of talent management.

Three hypotheses were formulated in this study. They allow us to conclude that there is a direct relationship between the size of an organisation and its talent management practices in the Czech and Slovak contexts. In hypothesis $\mathrm{H} 1$, we assumed that small and medium-sized enterprises in the Czech Republic and Slovakia adopted the inclusive approach to talent management and that large enterprises adopted the exclusive approach. The results, however, show different conclusions. According to the earlier surveys, the inclusive approach is consistent with the philosophy followed by most SMEs, according to which all employees are valued and have the opportunity to be a talent, which motivates them to remain. By contrast, large firms, which are mostly performanceorientated, tend to adopt high-performance and high-potential approaches. Therefore, our results are surprising. Further research dealing with the specifics of talent management in transition economies is necessary. In hypothesis $\mathrm{H} 2$, we assumed that large organisations tended to use talent management strategies that align with their company strategy, unlike SMEs, which adopt an ad hoc rather than strategic approach to talent. Hypothesis $\mathrm{H} 3$ confirmed that there are differences in the implementation of talent management practices between large and small and medium-sized enterprises in the Czech Republic and Slovakia. Talent management is preferred as a modern approach to HR management by large enterprises, where the need for talented individuals is objectively greater than in smaller enterprises. Most differences concerned talent assessment, talent development, and talent retention. We assume that there is a relationship between talent management practices and SMEs' specific features and human resource management levels. Moreover, the economic situations in both countries are an important factor affecting the implementation of SMEs' talent management.

These findings are not particularly surprising, as talent management is not a key issue for most Czech and Slovak organisations, particularly SMEs [13], [16]. Nevertheless, talent management is a crucial challenge for all organisations aiming to enhance their competitive advantages.

The research survey raises a number of important issues that ought to be considered by enterprises during their engagement in talent management. These findings contribute to a better understanding of talent management implementation in different types of enterprises and may also provide a useful platform for future research in this area. 


\section{Research Limitations}

This study has several limitations that call for further research. First, its sample was relatively small. The number of participating organisations was insufficient for generalising the findings to all organisations. Nevertheless, we argue that the finding add to our understanding of the current TM situation for companies in both countries. Another limitation is that the target group consisted only of owners, CEOs, and HR managers. Although they are expected to play a key role in implementing talent management, other target groups (such as employees) could be included in future research for a better understanding of talent management issues. Third, the narrow scope of talent management issues represents another limitation. Our survey focused on talent management practices (the 'how') rather than on 'who' is considered talented or 'why'. The latter talent management issues will have to be analysed.

\section{References}

[1] BERSIN, J. Predictions for 2013: Corporate Talent, Leadership and HR-Nexus of Global Forces Drives New Models for Talent [online]. Bersin by Deloitte, 2013 [cit. 2015-03-09]. 57 p. (PDF). Available from: http://www.ihrc.ch/ wp-content/uploads/2013/03/predictions-2013final-1.pdf.

[2] COOKE, F.L., SAINI, D.S., WANG, J. Talent management in China and India: A comparison of management perceptions and human resource practices. Journal of World Business. 2014, Vol. 29, Iss. 2, pp. 225- 235. ISSN 10909515. DOI: $10.1016 / j . j w b .2013 .11 .006$.

[3] COLLINGS, D., MELLAHI, K. Strategic talent management: A review and research agenda. Human Resource Management Review. 2009, Vol. 19, Iss. 4, pp. 304-313. ISSN 1053-4822. DOI: 10.1016/j.hrmr.2009.04.001.

[4] COLLINGS, D.G., MELLAHI, K. Commentary on: Talent-innate or acquired? Theoretical considerations and their implications for talent management. Human Resource Management Review. 2013, Vol. 23, Iss. 4, pp. 322-325. ISSN 1053-4822. DOI: 10.1016/j.hrmr.2013.08.003.

[5] COLLINGS, D.G., SCULLION, H., VAIMAN, V. European perspectives on talent management. European Journal of International Management. 2011, Vol. 5, Iss. 5, pp. 453-462. ISSN 1751-6757.

[6] EGEROVÁ, D., et al. Integrated Talent
Management-Challenge and Future for Organizations in Visegrad Countries. Plzeň: Nava, 2013. ISBN 978-80-7211-454-2.

[7] EGEROVÁ, D. Talent management: Driver for Competitive Advantage. In: Proceedings of the 24th International Business Information Management Association Conference. Milan: International Business Information Management Association (IBIMA), 2014. pp. 141-147. ISBN 978-0-9860419-3-8.

[8] FESTIG, M., SCHÄFER, L., SCULLION, H. Talent management in medium-sized German companies: an explorative study and agenda for future research. The international Journal of Human Resource Management. 2013, Vol. 24, Iss. 9, pp. 1872-1893. ISSN 0958-5192. DOI: 10.1080/09585192.2013.777538.

[9] GALLARDO-GALLARDO, E., DRIES, N., GONZÁLEZ-CRUZ, T.F. What is the meaning of 'talent' in the world of work? Human Resource Management Review. 2013, Vol. 23, Iss. 4, pp. 290-300. ISSN 1053-4822. DOI: 10.1016/j. hrmr.2013.05.002.

[10] GUTHRIDGE, M., KOMM, A.B., LAWSON, $\mathrm{E}$. The people problem in talent management. The McKinsey Quarterly. 2006, Vol. 2, pp. 6-11. ISSN 0047-5394.

[11] HARTMANN, E., FEISEL, E., SCHOBER, $\mathrm{H}$. Talent management of western MNCs in China: Balancing global integration and local responsiveness. Journal of World Business. 2010, Vol. 45, Iss. 2, pp. 169-178. ISSN 10909515. DOI: 10.1016/j.jwb.2009.09.013.

[12] HATUM, A. Next Generation Talent Management. Basingstoke: Palgrave Macmillan, 2010. ISBN 978-0-230-27929-2.

[13] HORVÁTHOVÁ, P. Talent management. Praha: Wolters Kluwer, 2011. ISBN 978-807357-665-3.

[14] ILES, P., CHUAI, X., PREECE, D. Talent Management and HRM in Multinational companies in Beijing: Definitions, differences and drivers. Journal of World Business. 2010, Vol. 45, Iss. 2, pp.179-189. ISSN 1090-9516. DOI: 10.1016/j.jwb.2009.09.014.

[15] KADEŘÁBKOVÁ, A., et al. Zpráva o situaci a rozvoji lidských zdrojů $v$ malých a středních podnicích. Praha: Národní vzdělávací fond, 2003.

[16] KOUBEK, J. Řizení lidských zdrojü. $4^{\text {th }}$ ed. Praha: Management Press, 2010. ISBN 97880-7261-168-3.

[17] LATHUKA, M. Talent management in Russian companies: domestic challenges and 
international experience. The International Journal of Human Resource. 2014, Vol. 26, Iss. 8, pp. 1051-1075. ISSN 0958-5192. DOI: 10.1080/09585192.2014.922598.

[18] LEWIS, R.E., HECKMAN, R.J. Talent management: A critical review. Human Resource Management Review. 2006, Vol. 16, Iss. 2, pp. 139-154. ISSN 1053-4822. DOI: 10.1016/j.hrmr.2006.03.001.

[19] MANPOWERGROUP. Talent shortage survey. 2013. Research results [online]. Milwaukee: Manpower group, 2013 [cit. 2015-02-01]. 48 p. (PDF). Available from: //http://www.manpowergroup.com/wps/ wcm/connect/587d2b45-c47a-4647-a7c1e7a74f68fb85/2013_Talent_Shortage_Survey_ Results_US-high+res.pdf?MOD=AJPERES.

[20] MEYERS, M.C., WOERKOM, M. The influence of underlying philosophies on talent management: Theory, implications for practice, and research agenda. Journal of World Business. 2014, Vol. 49, Iss. 2, pp. 192-203. ISSN 1090-9516. DOI: 10.1016/j. jwb.2013.11.003.

[21] McDONNELL, A., et al. Developing tomorrow's leaders-Evidence of global talent management in multinational enterprises. Journal of World Business. 2010, Vol. 45, Iss. 2, pp. 150-160. ISSN 1090-9516.

[22] MENDEZ, L.A.F. Senior Managers and SMEs' Propensity to Quality Improvement Programs - A Comparative Analysis. E+M Economics and Management. 2013, Vol. 16, Iss. 4, pp. 89-103. ISSN 1212-3609.

[23] MUNK, M., et al. Methodology Design for Data Preparation in the Process of Discovering Patterns of Web Users Behaviour. Applied Mathematics \& Information Science. 2013, Vol. 7, Iss.1, pp. 27-36. ISSN 1935-0090.

[24] NILSSON, S., $\quad$ ELLSTRÖM, P. Employability and talent management: Challenges for HRD. European Journal of Training and Development. 2012, Vol. 36, No. 1, pp. 26-45. ISSN 2046-9012. DOI: 10.1108/03090591211192610.

[25] OLTRA, V., VIVAS-LÓPEZ, S. Boosting organizational learning through team-based talent management: what is the evidence from large Spanish firms. The international Journal of Human resource Management. 2013, Vol. 24, Iss. 9, pp.1853-187. ISSN 0958-5192. DOI: 10.1080/09585192.2013.777540.

[26] PARRY, E., STAVROU, E., LAZAROVA, M. (Eds.). Global Trends in Human Resource
Management. Basingstoke, UK: Palgrave Macmillan, 2013. ISBN 978-0-230-35483-8.

[27] PISZCZUR, R. Vliv strategického rízení na výkonnostní kritéria organizace. In: Sborník z mezinárodní vědecké konference INPROFORUM 2013. České Budějovice: Jihočeská univerzita $v$ Českých Budějovicích, 2013. pp. 227-232. ISBN 978-80-7394-440-7.

[28] SCHIEMANN, W. Reinventing talent management: How to maximize performance in the new marketplace. Hoboken, N.J.: Wiley, 2009. ISBN 978-0-470-45226-4.

[29] SCHULER, R.S., JACKSON, S.E., TARIQUE, I. Global talent management and global talent challenges: Strategic opportunities for IHRM. Journal of World Business. 2011, Vol. 46, Iss. 4, pp. 506-516. ISSN 1090-9516. DOI: 10.1016/j.jwb.2010.10.011.

[30] SILZER, D., DOWELL, B.E. StrategyDriven Talent Management. A Leadership Imperative. San Francisco: John Wiley \& Sons, 2010. ISBN 978-0-7879-8847-0.

[31] SKOKAN, K., PAWLICZEK, A., PISZCUR, R. Strategic planning and Business Performance of Micro, Small and Medium-Sized Enterprise. Journal of Competitiveness. 2013, Vol. 5, Iss. 4, pp. 57-72. ISSN 1804-1728.

[32] SKUZA, A., SCULLION, H., McDONNELL, A. An analysis of talent management challenges in a post-communist country: the case of Poland. The International Journal of Human Resource Management. 2013, Vol. 24, Iss. 3, pp. 453-470. ISSN 0958-5192. DOI: 10.1080/09585192.2012.694111.

[33] STAHL, G.K., et al. Six Principles of Effective Global Talent Management. MIT Sloan Management Review. 2012, Vol. 53, Iss. 2, pp. 24-33. ISSN 1532-9194.

[34] TANSLEY, C., KIRK, S., TIETZE, S. The currency of talent management $-A$ reply to "talent management and the relevance of context: Towards a pluralistic approach". Human Resource Management Review. 2013, Vol. 23, Iss. 4, pp. 337-340. ISSN 1053-4822. DOI: 10.1016/j.hrmr.2013.08.004.

[35] THUNNISSEN, M., BOSELIE, P., FRUYTIER, B. Talent management and the relevance of context: Towards a pluralistic approach. Human Resource Management Review. 2013, Vol. 23, Iss. 4, pp. 326-336. ISSN 1053-4822. DOI: 10.1016/j.hrmr.2013.05.004.

[36] THUNNISSEN, M., BOSELIE, P., FRUYTIER, B. A review of talent management: infancy or a adolescence? The International 
Journal of Human Resource Management. 2013, Vol. 24, Iss. 9, pp. 1744-1761. ISSN 09585192. DOI: 10.1080/09585192.2013.777543.

[37] VÁCLAVKOVÁ, L., et al. Specifika rízení lidských zdrojů $v$ malých a středních podnicích a neziskových organizacích [online]. Praha: VŠE, 2007 [cit. 2015-03-09]. Research report, project IGA 18/05. Available from: http://www. neziskovky.cz/sdata/ Vyzkumna_zprava_z projektu_476.pdf.

[38] VAIMAN, V., HOLDEN, N.J. Talent management's perplexing landscape in Central and Eastern Europe. In: SCULLION, H., COLLINGS, D. (Eds.). Global Talent Management. London: Routledge, 2011. ISBN 978-0-415-87170-9.

[39] VAIMAN, V., SCULLION, H., COLLINGS, D.G. Talent management decision making. Management Decision. 2012, Vol. 50, No. 5, pp. 925-941. ISSN 0025-1747. DOI: 10.1108/00251741211227663.

[40] VEBER, J., et al. Podnikání malé a střední firmy. Praha: Grada, 2005. ISBN 978-80-2474520-6.

[41] WANG, C., WALKER, E.A., REDMOND, J.L. Explaining the lack of strategic planning in SMEs: The importance of owner motivation. International Journal of Organisational Behaviour. 2007, Vol. 12, Iss. 1, pp. 1-16. ISSN 1440-5377.
[42] ZHANG, S., BRIGHT, D. Talent definition and talent management recognition in Chinese private-owned enterprises. Journal of Chinese entrepreneurship. 2012, Vol. 4, No. 2, pp. 143-163. ISSN 1756-1396. DOI: 10.1108/17561391211242753.

PaedDr. Dana Egerová, Ph.D. University of West Bohemia Faculty of Economics

Department of Business Administration and Management egerova@kpm.zcu.cz

Ing. Drahoslav Lančarič, PhD. Slovak University of Agriculture, Nitra Faculty of Economy and Management Department of Management drahoslav.lancaric@uniag.sk

doc. PaedDr. Ludvík Eger, CSc. University of West Bohemia Faculty of Economics

Department of Marketing, Trade and Services leger@kmo.zcu.cz

Ing. Radovan Savov, PhD. Slovak University of Agriculture, Nitra Faculty of Economy and Management Department of Management radovan.savov@uniag.sk 


\title{
Abstract
}

\section{PERSPECTIVES OF TALENT MANAGEMENT: EVIDENCE FROM CZECH AND SLOVAK BUSINESS ORGANISATIONS}

\author{
Dana Egerová, Drahoslav Lančarič, Ludvík Eger, Radovan Savov
}

Despite the growing attention being paid to talent management in the literature, little empirical research has been conducted on applying talent management in various organisations, particularly in small and medium-sized enterprises. Therefore, our empirical survey examines talent management practices from the perspective of different sized enterprises in the Czech Republic and Slovakia. The findings are based on data collection from 174 enterprises in the Czech Republic and Slovakia. Overall, the survey indicates that talent management is not of primary concern to most organisations in the Czech Republic and Slovakia. These findings are not particularly surprising, as talent management is not a key issue for most organisations, particularly SMEs. Nevertheless, we argue that talent management is a crucial challenge for all organisations aiming to enhance their competitive advantages. This study's major findings prove that enterprise size is a relevant determinant of approaches to talent management and its practice within the enterprises. Several important differences between SMEs and large organisations were found. First, SMEs adopt a more exclusive approach to talent than do large firms, where an inclusive approach dominates. Furthermore, SMEs' strategic approach to talent management is limited, with most adopting an ad hoc approach to talent management practices. Thus, the shift towards holistic and strategic approaches to talent management constitutes one of the most important challenges for those organisations. The research survey raises a number of important issues that should be considered by enterprises when they engage in talent management. The survey has added to our understanding of the talent management implementation in different types of enterprises.

Key Words: Talent management, small and medium-sized enterprises, large organizations, Czech Republic, Slovakia.

JEL Classification: M12, M14.

DOI: 10.15240/tul/001/2015-4-008 